\title{
SIDRAK AND BOKKUS: AN EARLY MODERN READER RESPONSE
}

Abstract: The Middle English version of the encyclopedic verse dialogue Sidrak and Bokkus has received little attention in recent scholarship, and hence questions about its organization and appeal to readers remain unanswered. Discussing a previously unexplored version of the text in the early modern alchemical miscellany Bibliotheca Philosophica Hermetica, Amsterdam, MS M199, this article demonstrates how the text was read and interpreted by one late sixteenth-/early seventeenth-century reader in particular. Although the copyist took his text from the edition of the Middle English Sidrak and Bokkus printed in the 1530s by Thomas Godfray, he abbreviated and restructured the text to fit his own interests and needs. The numerous marginal annotations reveal that the copyist/annotator interpreted at least parts of the text as having alchemical or metallurgical significance. He also saw parallels in Sidrak and Bokkus to literary texts, most notably Chaucer's Monk's Tale, adding references to William Thynne's third edition of the Canterbury Tales (c. 1550). The article thus provides detailed information both on the interpretation of Sidrak and Bokkus in early modern England and on reading practices in the period more generally. ${ }^{1}$

\section{INTRODUCTION}

Since T.L. Burton's edition of the Middle English Sidrak and Bokkus in 1998-1999, scholars have had access to an excellent edition of the encyclopedic verse dialogue between the Christian prophet Sidrak and the heathen king Bokkus. ${ }^{2}$ Sidrak and Bokkus provides for fascinating reading: a preface where Sidrak defeats the devil and smashes idols with the help of the power of God and various angels sets the scene for Bokkus's questions and Sidrak's subsequent exposition on a multitude of issues, from the nature of God to why sea water is salty and how many countries there are in

1 I am grateful to Molly Zahn for reading and commenting on an earlier draft of this article, and especially for pointing out the parallel to the Book of Proverbs; to Professor Linda E. Voigts for introducing me to Bibliotheca Philosophica Hermetica MS M199; and to Dr. Theodor Harmsen of the Bibliotheca Philosophica Hermetica, Amsterdam, for providing me with material and information about the manuscript. I am also grateful to the Bibliotheca Philosophica Hermetica for allowing me to cite material from MS M199.

2 Sidrak and Bokkus: A Parallel-Text Edition from Bodleian Library, MS Laud Misc. 559 and British Library, MS Lansdowne 793, ed. T. L. Burton, 2 vols., EETS OS 311-312 (Oxford: Oxford UP, 1998-1999). 
the world. As shown by the many extant manuscripts, the text attracted a great deal of attention in late medieval and early modern England. But despite the indisputable importance and popularity of the text and despite the existence of Burton's edition, there have been very few studies in the last eight years that address the many unresolved problems with the text. For example, it remains uncertain what genre of writing the text belongs to (encyclopedia, romance, history, dialogue etc.), and how readers dealt with the text's seemingly disorganized structure. ${ }^{3}$

This article addresses some of these issues by discussing a previously unexplored English version of Sidrak and Bokkus found in Bibliotheca Philosophica Hermetica, Amsterdam, MS M199 (henceforth BPH M199), a late sixteenth-/early seventeenth-century alchemical miscellany. ${ }^{4}$ BPH M199 is a striking witness of how Sidrak and Bokkus was approached in the early modern period. It is heavily abbreviated and exhibits a revised structure that appears to reflect the copyist's interests. It also contains numerous marginal comments from one reader in particular that suggest how the text was digested and what texts it was used in conjunction with. For example, passages that originally had no connection with alchemy or metallurgy have been (re)interpreted in the light of alchemical or metallurgical ideas. Moreover, there are references to several literary works such as Chaucer's Monk's Tale and Stephen Batman's The Trauayled Pylgrime (1569), pointing to at least one annotator's wide reading. What is more, the exact printed edition of Chaucer's work that the annotator used can be established. Given the increasing scholarly interest in reading practices in early modern England and the paucity of data to determine such practices, the importance of $\mathrm{BPH}$ M199 is clear. Discussing the copying, structure, and annotation of BPH M199, I will show that BPH M199's copy of Sidrak and Bokkus was studied with care, and the reader (or readers) approached it as a work of serious scholarship.

3 See e.g. Robert E. Nichols, "Sidrak and Bokkus on the Atmospheric and Earth Sciences", Centaurus 12 (1968): 215-32, at 215; William H. Holler, "The Ordinary Man's Concept of Nature as Reflected in the Thirteenth-Century French Book of Sydrac", The French Review 48 (1975): 526-38, at 527; Burton 1998, xxv-xxxix.

4 For the Bibliotheca Philosophica Hermetica, Amsterdam, see <www.ritmanlibrary.nl/>. Burton does not record this manuscript. Boffey and Edwards list it as being sold by Christie's in 1991, but apparently did not know that it was bought by the Bibliotheca Philosophica Hermetica; Julia Boffey \& A. S. G. Edwards, The New Index of Middle English Verse (London: The British Library, 2005) no. 2147, item 7. 


\section{The Manuscript, the Copyist, and the Annotator(s)}

BPH M199, which covers 399 paper leaves, is an alchemical miscellany measuring $350 \times 200 \mathrm{~mm} .{ }^{5}$ It is written in a number of sixteenth- and seventeenth-century hands and was probably compiled over a period of time. Watermark evidence points to a date mainly in the second half of the sixteenth century (1548, and 1558-1569). However, in fol. $393 \mathrm{r}$, there is a note ("out of Rob: Dollens manuscript 1647") that suggests that the manuscript was added to at least up until 1647 or that BPH M199 was put together in its present format after this date. I have found no information about the history of the volume between the middle of the seventeenth century and 1991, when it was acquired by the Bibliotheca Philosophica Hermetica.

In the late sixteenth and early seventeenth centuries, BPH M199 seems to have been in the ownership of an English alchemist by the name of Edward Dekyngstone, whose name appears in two notes in the manuscript. Dekyngstone may also have copied out several texts in the volume, although this assumption remains tentative. ${ }^{6}$ Although Dekyngstone's name appears in a number of other manuscripts (including London, British Library, MSS Sloane 2170, 3180, 3630, and 3684), very little seems to be known about him. The volumes connected with him mainly contain alchemical texts, which attests to his alchemical interests, but I have not been able to discover anything else about him. ${ }^{7}$

BPH M199 mainly incorporates alchemical texts of various kinds. Written in English as well as Latin, in verse as well as prose, the texts constitute both well-known alchemical opera by famous authors and anonymous writings and notes. ${ }^{8}$ With such contents, BPH M199 is a fairly typical example of alchemical manuscript books of the early modern period. ${ }^{9}$ In addition to

5 The only description available of BPH M199 is from Christie's auction catalogue from June 26, 1991. I am grateful to Dr. Theodor Harmsen of the Bibliotheca Philosophica Hermetica for providing me with this description. Based on an inspection of a microfilm of BPH M199, I have supplied some additional information on the manuscript's age, content, owner, and copyist in Peter Grund, "A Previously Unrecorded Fragment of the Middle English Short Metrical Chronicle in Bibliotheca Philosophica Hermetica M199", English Studies 87 (2006): 277-93. In my discussion here, I will rehearse some of my findings in that article, but I will deal with Sidrak and Bokkus in particular, which was not discussed there.

6 Grund 2006, 278-79.

7 For a fuller discussion, see Grund 2006, 278-79.

8 For the texts written in English, see Linda E. Voigts \& Patricia D. Kurtz, Scientific and Medical Writings in Old and Middle English: An Electronic Reference, CDROM (Ann Arbor: U of Michigan P, 2000). BPH M199 is listed as "Bibliotheca Philosophica Hermetica 'Dekyngstone"'.

9 Cf. Charles Webster, "Alchemical and Paracelsian Medicine", in Health, Medicine and Mortality in the Sixteenth Century, ed. Charles Webster (Cambridge: Cambridge UP, 1979) 311. 
the alchemical texts, it also contains some texts on magic and a few medical recipes, which are not uncommon in other alchemical collections. More surprising is the inclusion of a fragment of the Middle English verse chronicle, The Short English Metrical Chronicle, and Sidrak and Bokkus. I have argued elsewhere that the former was probably copied because it was interpreted as having an alchemical message. ${ }^{10}$ As I will show, a similar (re)interpretation is evident in Sidrak and Bokkus.

Sidrak and Bokkus appears in three sections in BPH M199: 97r-108v, $161 \mathrm{v}-169 \mathrm{v}, 307 \mathrm{v}-330 \mathrm{v}$. These sections were probably copied at different times. This is suggested by the fact that both the second and third sections begin on a verso, whereas the recto contains an unrelated text: in fol. $161 \mathrm{r}$ "Hermes de Lapide philosophico", and in fol. $307 \mathrm{r}$ the end of "Secreta Rasis occultata in Libro Luminum de Secretis nature". ${ }^{11}$ Despite appearing at different points of the manuscript, Sidrak and Bokkus is copied in one and the same hand throughout the text, a hand which is different in appearance from other hands of the manuscript (see below). The copyist has left two metatextual comments. The very beginning of the text (fol.97r) is introduced by the following note: "Certayne notes of vnderstandynge: Drawne owt by me, fowrthe of the Questions of the Historye, of kynge Boccus, and Sydracke: wherof ther be. CCClxv: questions". A similar note is found before two later questions: "Theis notes, herafter followynge: I tooke owt of Certayne Questions: for my better vnderstandynge:” (fol. 108 r). Although these notes in themselves do not provide any information about the copyist, they are important in that they echo an earlier note in BPH M199, which may provide a clue to the identity of the copyist. The note in question appears in fol. $41 \mathrm{v}$, preceding an alchemical text: "Drawene owt by me $\mathrm{E}$ Dekyngstone: A Diciple. of philosophie”. As mentioned above, BPH M199 may have been in the ownership of Edward Dekyngstone, and he may even have copied out some of the texts.

Naturally, the similarity of the notes is not firm evidence for Dekyngstone being the copyist; a match in handwriting would provide a clearer link. Unfortunately, a comparison of the handwriting is far from conclusive. The handwriting of Sidrak and Bokkus and that of the Dekyngstone note do share several characteristics: they both contain a mixture of secretary and italic letter-forms, and many letter-forms are strikingly similar. However, a positive match cannot be established. Complicating the analysis is the character of the

10 Grund 2006, 281-84.

11 Different copying sessions may also account for why Question 32 of Sidrak and Bokkus appears twice in BPH M199 (fols. 97v and 319v-20r), the copyist perhaps forgetting that he had already copied it earlier on. In my transcription of text from the manuscript, the guiding principle has been to stay as close to the original manuscript as possible: capitalization and punctuation have been retained. Abbreviations have been expanded using italics. Exceptions are $\left\langle\mathrm{y}^{\mathrm{e}}\right\rangle$ (for the $),\left\langle\mathrm{y}^{\mathrm{ei}}>\right.$ (for they), $\left\langle\mathrm{y}^{\mathrm{is}}>\right.$ (for this), $\left.<\mathrm{y}^{\mathrm{t}}\right\rangle$ (for that), which have all been kept. 
handwriting of Sidrak and Bokkus. The copyist writes very carefully, many times with a writing implement with a broad nib. Some words have even been written in a larger type of script and then often with italic letter-forms, probably for the purpose of emphasis or highlighting. Paying special attention to layout and spacing, the copyist obviously took pains to produce a neat, elegant text. ${ }^{12}$ This opens up the possibility that the handwriting of the Dekyngstone note and that of Sidrak and Bokkus are indeed the same, only one represents the copyist's less careful, workaday hand and the other a deliberately ornamented hand that was adopted as somehow more suitable to the copying of Sidrak and Bokkus. This question must remain open.

Sidrak and Bokkus is heavily annotated, as will be discussed in detail later. Most of the comments appear to be in the same hand as the text proper. However, they were probably added over a period of time or at least at different readings, judging by the appearance of the handwriting. A very limited number of comments may even have been added by one or more subsequent, though contemporaneous, readers. An inspection of the actual manuscript, which has not been possible for this study, would possibly reveal a much clearer and more detailed chronology of these marginal comments than can be discerned from a study of the microfilm copy.

\section{BPH M199 AND GODFRAY's EDITION (1530?)}

A collation of the extant copies of Sidrak and Bokkus ${ }^{13}$ and BPH M199 reveals that BPH M199 was not copied from any of the now extant manuscripts; instead it derives from the version printed by Thomas Godfray in the 1530s. The match between the two is unmistakable, as Godfray's edi-

12 Christie's auction catalogue (June 26, 1991) describes the hand of Sidrak and Bokkus as archaic, but that is hardly the case. The use of italic letter-forms, which was fairly new at the end of the sixteenth century, demonstrates that the handwriting is not old-fashioned. See Anthony G. Petti, English Literary Hands from Chaucer to Dryden (London: Arnold, 1977) 20; Jean F. Preston \& Laetitia Yeandle, English Handwriting 1400-1650: An Introductory Manual (Binghamton, NY: Medieval \& Renaissance Texts \& Studies, 1992) viii; Giles E. Dawson \& Laetitia Kennedy-Skipton, Elizabethan Handwriting 1500-1650: A Manual (New York: Norton, 1966) 12.

13 I have based my collation on the edition and variant readings presented by Burton 1998-1999. I have also consulted the Early English Books Online <http:// eebo.chadwyck.com/home> version of Godfray's edition (STC 3186, from an original in the British Library). The exact date of this printing is not clear. Discussing various conjectures about the date in previous research, Burton 1998, lxxiii, suggests the approximate date "? 1530" since other books by Godfray that can be dated all come from post-1530. Early English Books Online suggests the date 1537 and refers to the STC conjecture about the date. 
tion is substantially different from the extant manuscript copies discussed by Burton. ${ }^{14}$ The striking closeness between BPH M199 and Godfray's edition can be seen in the following text comparison.

BPH M199 (fol. 169v)

The .4. Question:

which was the fyrste thynge. that God Made askyd y $\mathrm{e}^{\mathrm{e}}$ kynge? Sir, quod Sydracke, vnto me lyste: A fayer paleys, he made fyrste: full, of Blysse: \& full of light: That $\mathrm{y}^{\mathrm{e}}$ kyngedome, of heven, hight: After that, he made $\mathrm{y}^{\mathrm{e}}$ worlde thus: And hell, depe: vnderneathe vs: Into heven. he dyd his freendes, let: his foes. in hell: weare Subiecte: Man, made he than, as was his wyll: $\mathrm{y}^{\mathrm{e}}$ vnbre: of Angells, to fulfyll: Insteade of theym, that fall wore: And shulde in heaven, come no more: Angell. \& Man: shall felowes be: for one God. honors bothe hee, \& wee: That is God, of Might, Moste: father. Sonne. and holy. Gooste./.
Godfray (fol. Fir)

II The .iiii. questyon.

II Which was the fyrst thynge That god made askyd the kynge Syr quod Sydrac vnto me lyst A fayre paleys made he fyrst full of blys and full of lyght That the kyngdom of heuyn hyght After made he the world thus And helle depe vnderneth vs Into heuyn his fryndes he dyd lett His foes in hell were subiecte Man made he than as was his wyll The vmbre of aungels to fulfyll Instede of them that fall wore And shuld in heuyn come no more Aungel and man shall felowes be

For one god honorys both he and we That is god of myght most Father/ sonne and holy goost
Burton 1998, 118-20

[Bodleian Laud Misc. 559]

'Which was now the firste thynge That God made?' asked pe kynge. 'Sir,' quod Sidrak, 'vnto my lust A full fayre palys made he fyrst Full of blisse and full of light That pe kyngdome of heven hight; Sethens made he pe worlde pus And sethen helle depe vndir vs. In heven his frendes he lete; His ffoes to helle falle full depe. Man made he panne, as was his will, The noumbre of aungelis to fulfill Instede of hem pat fallen were And shulde in heven come no moore. Aungell and man shall feris be, For oon God worshipen he Thatt is God of myghtys mooste, Fader and Sone and Holi Goste.'

The numbering of the questions is also virtually identical in the two versions, although BPH M199 does not follow the printed edition's organization of the questions (as I will show in detail later). For example, the questions numbered 389, 390, and 391 in Bodleian Library, Laud Misc. 559 (edited by Burton) are 352, 353, and 354 in both Godfray's edition and BPH M199. ${ }^{15}$ Even when Godfray's edition contains clear errors, BPH M199 follows the numbering in the printed edition. For example, both have assigned the same number to two consecutive questions in three cases: Questions 131, 330, and 354. In two other cases, there are mistakes in the edition that have been followed in BPH M199 with some modification. The question that follows 142 has been mislabeled in Godfray's edition as 43 instead of 143; BPH M199 assigns it the number $44 .{ }^{16}$ Godfray's edition mistakenly numbers Question 282 as 82; again, BPH M199 is close, but records it as Question 84.

Although BPH M199 and Godfray's edition are often virtually identical, there are also differences. BPH M199 frequently does not retain the verse layout of Godfray's edition and sometimes restructures lines into prose by

14 Burton 1998, liii-lxxiii.

15 Only one of the versions printed by Burton contains continuous numbering of the questions; the other version, British Library, MS Lansdowne 793, uses a system based on a division of the text into four books.

16 BPH M199 also includes the "real" Question 44 in fols. $167 \mathrm{v}-68 \mathrm{r}$. 
changing the word order, as in the following example about the birth of God's son from a maiden.

BPH M199 (fol. 100r)

he shall light in hyr. \& she, inviolate: And shall dwell, in hir, right .9. monthes: for whie?

he shall fullfyll, the ix. orders of Angells: (that are styll, in heaven) with Manes kynde, that shalbe, Borne: and have come fowrthe, heare byforne:.
Godfray (fols. Giiir-v)

She inuyolate/ shall he in her lyght And dwell in her .ix. monthes ryght For the .ix. orders shall he fulfyll Of aungels that in heuen are styll With mannes kynd that shall be borne And forthe haue comen here beforne

BPH M199 also appears to update the language of the edition in a few cases, replacing archaic or obsolete Middle English words with more current early modern vocabulary. This strategy is probably behind changes such as "sholde take" (fol.99r) for "nam" (fol. Giiv), "suerly" (fol. 161 v) for "sykerly" (fol. Siiiir), "lowse” (fol. 167 r) for "lese” (fol. Kir), "dwell” (fol.313 r) for "wone" (fol. Tiir), "a rod, or wande" (fol.313v) for "yarde" (fol. Tiv), and "knowes" (fol.316r) for "wot" (P2iiiir) ${ }^{17}$.

More substantial differences between BPH M199 and Godfray's edition are rare. In Question 57 (which is 67 in Godfray's edition), BPH M199 (fol. $315 \mathrm{r}$ ) leaves out a line: "A man may rekyn and fynde sone" (fol. Miiiiv). It may be argued that the line is not strictly necessary, but considering $\mathrm{BPH}$ M199's normally close adherence to Godfray's text and the absence of similar omissions, it should probably be attributed to a copying mistake. In Question 253, BPH M199 uses a different rhyming pair, "done ... none" (fol. 168 r), than Godfray's edition, "so ... to" (fol. I2 iv), which seems to be a result of a slight restructuring. Finally, in question 255, BPH M199 prefers " $\mathrm{y}^{\mathrm{e}}$ Daye of dome" (fol. $168 \mathrm{v}$ ) to Godfray's "the dome" (fol. I2 iir). Only a few more differences like these occur.

There is only one line in BPH M199 that seems to point to the copyist of BPH M199 having access to a slightly different version than Godfray's edition. Where BPH M199 carries the line "they weare with hyme, bothe wrouthe \& woode" (fol. 104 v), Godfray's edition has "They were for it ny wode" (Diiiv). Slightly surprisingly, BPH M199 is here much closer, though not identical, to the manuscripts printed by Burton: "They were wroth as they were wode". ${ }^{18}$ It is not clear how BPH M199's copyist came up with this line. Conflation from a manuscript is of course possible, but it begs the question why the copyist would have changed this one reading but no other. Perhaps the simplest answer is that the copyist added "wrouthe" as a gloss or explanation to "woode"; similar glossing does appear in the text. The connection to Burton's manuscripts would then be incidental.

17 After exhausting all the letters of the alphabet for the foliation, Godfray's edition starts from "A" again but uses a different font. I refer to letters in this second font as " 2 ", hence "P2iiiir".

18 Burton 1998, 42, 1. 670. 
A slightly peculiar reference appears before the preface of BPH M199's Sidrak and Bokkus: "In $\mathrm{y}^{\mathrm{e}}$ preface, of $\mathrm{y}^{\mathrm{e}}$ historye of kynge Boccus. And Sydracke: in folio. nono: this shall yow fynde: how he convertid Boccus. from the feende:" (fol.102r). Since Godfray's edition uses the commonplace system of letters and roman numerals to label the folios (e.g. Ai), the reference to a "folio nono" (the $9^{\text {th }}$ folio) would seem to be to a different version. However, there is a way to reconcile BPH M199's reference with Godfray's edition. The part of the preface where the BPH M199 extract begins is fol. Dir in Godfray's edition. If counted from the beginning of the preface instead of from the beginning of the book, folio Dir is indeed the ninth folio of the text of Sidrak and Bokkus in the British Library version of Godfray's edition that the Early English Books Online reproduces. ${ }^{19}$ The copyist thus seems to have followed his own foliation rather than that of Godfray's edition.

\section{Content and Organization}

The original Sidrak and Bokkus contains questions and answers on an abundance of issues, including the creation of the world, whether women can give birth to more than two children, and what color clothes it is best to wear. Many scholars have been puzzled by the text's seemingly disorganized structure, its contradictions, and its overlaps. For example, there are multiple questions that deal with the son of God spread out over the text: $39,40,46,72,381-393,395-397 .{ }^{20}$ As may be seen, there is a suite of questions on this particular topic in the upper three hundreds. But among these questions, there is little logical connection, although some questions are clearly related. For example, Questions 386-388 deal with aspects of the death of the son of God. After questions dealing with whether he will have a castle or a house on earth and similar issues, Question 395 reverts back to the topic of his death, requesting information on what signs will appear when he is dead. Such features of organization (or rather the lack thereof) are the norm rather than the exception. Burton argues that the problems that modern scholars have had with the organization and structure stem from their expectation that Sidrak and Bokkus was intended to be an encyclopedia. This expectation is, however, false, according to Burton, since

19 STC 3186. There is a problem with the Early English Books Online version in that folios Ciiiv and Ciiiir are missing. Bevan Blanchard of the Rare Books Department at the British Library, where the original is housed, informs me that folios Ciiiv and Ciiiir are present in the original; personal communication, February 19,2007 . The missing two pages are probably the result of a mistake in the scanning.

20 Since not all of these questions are included in BPH M199, I refer here to the numbers given by Burton in his edition. 
Sidrak and Bokkus was not intended "as a journal of scientific research or a systematic encyclopaedia". Instead, he claims that "[i]t belongs [...] to that class of sugared information transfer that has today come to be called (especially as applied to television programmes) 'infotainment'". ${ }^{21}$ Although it may be true that Sidrak and Bokkus was not originally intended as an encyclopedic work with a scholarly audience (like Bartholomeus Anglicus' De proprietatibus rerum), the question remains how it was regarded and used by medieval and early modern readers.

BPH M199 is a significant witness of Sidrak and Bokkus in that it gives us some clues as to how the text was approached. BPH M199 illustrates on many levels that at least one reader took a serious interest in the content of some questions. Whether this reader perceived the content as watered down or "sugared" is unclear. However, he expressedly copied out the questions "for my better vnderstandynge" (fol.108 r), and he seems to have tried to extract accurate information from the text, as we shall see below (Section 5 ). The original organization was apparently not agreeable to the copyist of BPH M199. Rather, since he was only interested in some questions or topics, he tried to reorganize the information so as to fit his needs.

BPH M199 contains eighty-two of the some 344 questions in Godfray's edition, representing a cross-section of topics found in the original Sidrak and Bokkus. ${ }^{22}$ Classifying and giving statistics on the type of issues included is not easy and perhaps not meaningful. ${ }^{23}$ The reason for this is that the

21 Burton 1998, xxxviii-ix.

22 As noted by Burton 1998, lxxi, Godfray's edition contains 344 questions although it claims to have 365 . The manuscript versions discussed by Burton differ in their number of questions. Bodleian Laud Misc. 559, for example, includes over 400.

23 For those interested, I add a list of the questions included in BPH M199 and their corresponding numbers in Burton's edition (MS Laud Misc. 559), citing BPH M199 first: $279=303 ; 280=304 ; 32=32 ; 23=22 ; 20=20 ; 14=14 ; 15=14$ (mistake in MS Laud); $16=15 ; 44=$ no number $(145) ; 1=$ no number $(1) ; 2=$ no number (2); preface $=$ preface 1l. 541-914 (with some omissions in $\mathrm{BPH}$ M199); $8=8 ; 237=238 ; 58$ (only a fragment in BPH M199) $=58 ; 133=135$; $227=227 ; 114=115 ; 145=145 ; 149=149 ; 141=$ no number $(143) ; 150=149$ (mistake in MS Laud); $344=380 ; 352=389 ; 353=390 ; 354=391 ; 354$ (mistake in BPH M199) $=392 ; 355=393 ; 252=269 ; 41=41 ; 40=40 ; 44=44$; $253=270 ; 254=271 ; 255=272 ; 84=306 ; 4=$ no number $(4) ; 131=134 ; 131$ $($ mistake in BPH M199) $=127 ; 132=128 ; 126=129 ; 302=333 ; 303=335$; $311=353 ; 312=355 ; 313=356 ; 314=357 ; 315=358 ; 147=147 ; 148=148$; $125=126 ; 127=130 ; 20=121 ; 119=120 ; 118=$ no number $(119) ; 65=65$; $66=66 ; 57=67 ; 330=$ no number $(377$ ?); $330($ mistake in BPH M199) $=$ no number (378?); $331=$ no number $(379$ ?); $332=$ no number $(380$ ?); $334=$ no number $(381$ ?); $335=$ no number $(382$ ?); $322=369 ; 29=$ no number $(30$ ? $) ; 30=$ no number (31); $31=31 ; 32=32 ; 33=33 ; 59=57$ (mistake for 59 in MS Laud); $64=64 ; 58=58 ; 74=74 ; 75=75 ; 80=80 ; 299=329 ; 300=330 ; 201=203$; $9=9 ; 239=240 ; 240=241 ; 146=146$. 
copyist may not have been interested or not exclusively interested in the main topic of the question. This is clearly suggested by the overall organizational or rather reorganizational strategy found in BPH M199. The copyist seems to have worked according to a principle of bringing together themes or topics, and thus takes a markedly different approach to that of the original compiler of Sidrak and Bokkus, who must have expected the reader to find relevant information on the same topic in other ways. ${ }^{24}$ The copyist's organization presents a kind of meandering thread, where a particular question appears to have been supplied because it elucidates some aspect of the previous question(s). Two sections may serve as illustrative cases. I have summarized the two below. ${ }^{25}$

\begin{tabular}{|c|c|c|}
\hline Question (fols.) & Heading & Connection \\
\hline $279(97 r)$ & Do angels keep human souls? & angels \\
\hline $280(97 \mathrm{r}-\mathrm{v})$ & $\begin{array}{l}\text { How can angels that have no body } \\
\text { show themselves to humans? }\end{array}$ & angels, body \\
\hline $32(97 v)$ & What is the complection and nature of the body? & body, soul \\
\hline $23(98 \mathrm{r})$ & How can the soul feel pleasure or pain? & soul \\
\hline $20(98 \mathrm{r}-\mathrm{v})$ & Which was made first, the soul or the body? & soul, body, Adam \\
\hline $14(98 v-99 r)$ & Why was not Adam doomed forever after his sin? & Adam, the redemption \\
\hline $15(99 \mathrm{r}-\mathrm{v})$ & $\begin{array}{l}\text { Why did not God send an angel } \\
\text { or a man to redeem Adam? }\end{array}$ & $\begin{array}{l}\text { Adam, the redemption, } \\
\text { the virgin birth }\end{array}$ \\
\hline $16(99 v-100 v)$ & $\begin{array}{l}\text { How will God be born by a maiden } \\
\text { and how will she remain a maiden? }\end{array}$ & the virgin birth, heaven \\
\hline $44(100 v-1 r)$ & How many heavens are there? & 3 heavens, God \\
\hline $1(101 \mathrm{r})$ & $\begin{array}{l}\text { Has God always existed and will } \\
\text { he always exist? }\end{array}$ & 3 heavens, God \\
\hline $2(101 \mathrm{r}-\mathrm{v})$ & Can God be seen? & God \\
\hline Question (fols.) & Heading & Connection \\
\hline $131(307 v)$ & Where does gold come from? & gold, sea (i.e. water?) \\
\hline $131(307 v-8 r)$ & How does hot water come out of the earth? & water, sulfur \\
\hline $132(308 \mathrm{r})$ & Where does sulfur come from? & sulfur, lightning \\
\hline $126(308 \mathrm{r}-\mathrm{v})$ & Where does lightning come from? & lightning, cloud \\
\hline $302(308 v)$ & Why does the wind stop when it rains? & cloud, wind and water \\
\hline $303(308 v-9 r)$ & Which is the stronger, wind or water? & wind and water \\
\hline
\end{tabular}

The first section (Questions 279-2), which begins BPH M199's extract from Sidrak and Bokkus, starts out with a question about angels, and the second question (280) also concerns angels. The question whether angels are corporeal or incorporeal (discussed in 280) seems to have triggered an interest in the constitution of the human body, which led to the addition of Question 32. This question helpfully says that the body is made of earth and

24 Most of the manuscripts that Burton discusses seem to include a table of contents. Granted that this table is not an easily accessible topic-by-topic index, it nevertheless gives the reader a digest of the content. Presumably this is how readers accessed individual topics, by locating the relevant questions.

25 The headings in the figure represent my modern paraphrase of the original headings. 
the soul of air. This mention of the soul is followed up in Question 23, and both the body and the soul appear in Question 20. The link to the next question (14) seems to be Adam. Question 20 mentions Adam's fall from grace, which is similarly the topic of Question 14. Although the next question (15) also follows the previous in other versions of Sidrak and Bokkus, there is a topical connection in that 15 also discusses the redemption. It further connects with 16 through the mention of the birth of God's son from a virgin, which is briefly mentioned in 15 . The subsequent jump to question 44 seems to have been triggered by the statement that God's son will "fullfyll, the .ix. orders of Angells: (that are styll in heaven)" (fol.100 r). Question 44 establishes that angels live in the second heaven (out of three). The taxonomy of three heavens is again referred to in Question 1, while the explicit connection between 1 and 2 may simply be (the nature of) God.

The second section represents the beginning of BPH M199's third extract from Sidrak and Bokkus. This section follows an organizational logic similar to that of the previous section. The first three questions $(131,131$, $132)^{26}$ also appear together in Godfray's edition (but not in the manuscripts edited by Burton). ${ }^{27}$ Since these questions already occur in sequence in the source, the copyist may simply have taken over the structure without reflection. However, there is also a logical connection between them that may have appealed to the copyist: they all deal with the origin of different substances; and there may even be more specific links. Question 131 (1) makes the point that gold may be found not only in mines but also on the beaches of the sea. The link to 131 (2) may simply be water, although this link is admittedly fairly weak. The association of 131 (2) and 132, on the other hand, is stronger: 131 (2) claims that hot springs are created by sulfur (or brimstone) in the earth close to the springs, and 132 helpfully makes clear where sulfur comes from. The jump to lightning in Question 126 may seem a bit abrupt, but in fact it fits in well with Question 132, which establishes that it is lightning that produces sulfur when it interacts with earth. Question 126 makes clear that lightning is created in clouds, and cloud seems to be the linking word picked up on in 302. This question mainly deals with the wind, but mentions the importance of clouds. That the real connection is indeed clouds is underscored by a marginal note: "Wyndes. $\mathrm{y}^{\mathrm{ei}}$ are A thine Clowde: havynge in hyme. little power: [...]". ${ }^{28}$ The logic between the sequence of 302 and 303 is clear: they both deal with different aspects of the wind, and to some extent water.

My argument about BPH M199's organization is similar to what has been argued about the structure of the biblical book of Proverbs, especially 10:1-22:16, and chapters 25-29. It has been shown that proverbs that

26 The duplication of 131 is also present in Godfray's edition.

27 They are 134, 127, and 128 in Bodleian Laud Misc. 559 (edited by Burton).

28 I will return to the issue of marginal annotation below. 
presumably appeared originally as separate items outside the Bible have been brought together to form pairs in the book of Proverbs. The links between these pairs are often thematic, although they may also be lexical or paronomastic (i.e. based on alliteration, assonance, word play etc.). Of specific interest is the obeservation that the proverb pairs seem to be part of progressively larger structures or thematic units. ${ }^{29}$ BPH M199's Sidrak and Bokkus is similar to Proverbs in that the original text has been reorganized on the basis of themes or topics. However, it is different in that it seems to present a meandering thread of topics or themes rather than clear pairings as Proverbs. Like Proverbs, on the other hand, BPH M199 may also have larger macrostructures. For example, in the first section cited earlier, the focus is on heaven, God, and angels (perhaps simply the Divine), while the second section reveals a focus on elements and metals. Although these larger units are fairly loose, they may reflect focal points of the copyist's interest at different stages of his writing.

Unfortunately, very much like the book of Proverbs, the connection between sequential questions or the structure of larger groupings is not always as obvious as the examples that I have listed above. ${ }^{30}$ There are sections where the copyist follows the source slavishly, and where the reason for the sequence is not apparent. This does not mean, however, that no connection existed; it only means that the associations that the copyist may have made are not readily obvious to us.

The copyist also made use of cross-references to create a coherent text and keep track of material that may be read in conjunction. ${ }^{31}$ The number of cross-references is not extensive, however: only fourteen of the eightytwo questions have been furnished with cross-references. ${ }^{32}$ Peculiarly enough, four of the cross-references are to questions that are not included in BPH M199 as it now stands. ${ }^{33}$ Perhaps the copyist was planning to add them later, but forgot to do so. An alternative explanation is that the version as it stands only preserves a portion of the original text, some sections or parts being lost since the copying. This is perhaps more plausible since the marginal notes were presumably added after the completion of the copying. A third, more complicated possibility is that the copyist still had access to the exemplar from which he copied Sidrak and Bokkus, and that his references are to the original. This would mean that he copied out the questions that were of immediate interest, "for [his] better vnderstandynge",

29 R. N. Whybray, The Composition of the Book of Proverbs (Sheffield: Sheffield Academic P, 1994) 62-131.

30 Whybray 1994, 66-68.

31 It is clear from the handwriting that the cross-references must have been added by the copyist and not a later annotator, although changes in letter size and quality make clear that they were probably not all added at the same sitting.

32 For cross-references to other works, see Section 5.

33 The references to the missing questions are 28, 289 (twice), and 62. 
presenting them in a more palatable order, but also that he had access to the full text for reference.

The cross-references are helpful in that they point to parallels, but they are less helpful in that they often simply refer to a number, such as “vide. 4. Que:" (fol. 99r). As BPH M199's Sidrak and Bokkus does not have a neat sequence, finding the right place would presumably have required some flicking through pages to locate the proper place. ${ }^{34}$ In other instances, the cross-reference is more elaborate, highlighting why the copyist thought the cited question was of relevance. Question 8 (fol. $107 \mathrm{r}$ ) is a case in point. Describing the nature of angels ("What shape: are Angell of: and what thinge can they doe?"), Sidrak makes clear to Bokkus that angels are incorporeal. This statement seems to have triggered the cross-reference to Question 280 (fol.97r), which clarifies how angels may appear to humans. The cross-reference helpfully advises to "looke in $\mathrm{y}^{\mathrm{e}} .280$. Q there shall yow Reade how he [i.e. an angel] takes A body. vpon hyme. \& then may yow see hyme:”.

The exact reason that triggered a cross-reference is not always easy to pinpoint, and many parallels remain unlinked. Personal interest obviously played a role here, but as with the general strategy of reorganizing the structure of the text, the associations and connections drawn by the copyist are not readily obvious in all instances.

\section{Marginalia}

Over the last decade or so, scholars have paid increasing attention to reading practices in early modern England. Among other things, it has been stressed that reading was a very active pursuit that frequently involved annotating texts in the form of underlining, marginal notes, and summaries or digests on interleaved pages. ${ }^{35}$ These annotations reveal a great deal about the reception of the text, and the interests and goals of the reader. The nu-

34 If the copyist still had access to the original, Godfray's edition, he could have consulted the table of contents at the beginning of the volume, which would have given him a folio reference for the specific question concerned.

35 Lisa Jardine \& Anthony Grafton, “'Studied for Action': How Gabriel Harvey Read his Livy", Past and Present 129 (1990): 30-78; William H. Sherman, John Dee: The Politics of Reading and Writing in the English Renaissance (Amherst: U of Massachusetts P, 1995) 53-78. For medieval texts, there is now a wealth of research on annotation. Especially rich is the literature on marginalia in Piers Plowman. See Carl J. Grindley, "Reading Piers Plowman C-Text Annotations: Notes Toward the Classification of Printed and Written Marginalia in Texts from the British Isles 1300-1641”, in The Medieval Professional Reader at Work: Evidence from Manuscripts of Chaucer, Langland, Kempe, and Gower, ed. Kathryn Kerby-Fulton \& Maidie Hilmo (Victoria, Canada: English Literary Studies, U of Victoria, 2001) fn. 2. 
merous annotations in BPH M199's Sidrak and Bokkus thus provide an excellent opportunity to explore the set of strategies used by one reader in particular, and the goals of that reading. ${ }^{36}$ In my discussion, I will draw on the taxonomy of annotations suggested by Sherman in his study of John Dee's reading practices, though with some modifications. ${ }^{37}$ One of the most important things to recognize is that a particular note or annotation can serve several purposes at the same time: it may highlight a certain passage and at the same time offer an interpretation. For example, BPH M199's annotations frequently combine an interpretive note with a Latin gloss. Although Sherman does not explicitly acknowledge such multiple-purpose notes, his examples betray similar overlaps in Dee's annotations.

The annotations in BPH M199 come in two forms: verbal and non-verbal. ${ }^{38}$ Of these two basic types, non-verbal is the least common. Asterisks appear twice as cross-reference cues, and a sword has been drawn in the margin to accompany a section narrating how an angel "Bearyng, A swearde: all Brennynge" (fol. $105 \mathrm{v}$ ) struck the devil and burned some idols. The notes also brim with alchemical or astrological sigils (like $\odot$ for sun or gold), but these usually occur within verbal notes. Underlining is fairly rare, and when it occurs, it is usually of one word only and in combination with a Latin gloss in the margin.

The verbal annotations, on the other hand, are manifold. Written in English or Latin, they consist of anything from a single word to a string of words or several complete sentences. These notes fall into a number of overlapping categories. The simplest kind of note is perhaps the topical note, which highlights the subject or issue of a particular passage. ${ }^{39}$ For example, the lines "But also some, as they do dye shall wende to heaven. the hye waye:" are accompanied by the marginal cue "Semita, Recta?", i. e. the straight or right way (fol. $168 \mathrm{r}$ ). ${ }^{40}$ Notes that exclusively perform this func-

36 As noted earlier, it remains unclear how many readers provided annotations, although the majority were clearly supplied by the copyist, probably at different sittings.

37 Sherman 1995, 81-83. Grindley 2001 proposes a comprehensive system of describing marginalia based on his investigations of a wide range of manuscripts in both Middle and Early Modern English. However, his categories of marginalia are clearly very much influenced by his focused attention to the manuscripts of Piers Plowman, and many categories are not relevant for a text like Sidrak and Bokkus. Sherman 1995, 81.

39 Sherman 1995, 81-82.

40 The question mark here probably does not mean that the copyist intended it to signal a question or to be an indication of uncertainty. Question marks could often function as exclamation marks in Early Modern English, which seems to be a more likely interpretation here. Although there are certainly examples of question marks in BPH M199 that accompany actual questions, there are also plenty of examples of question marks where an exclamatory or highlighting function 
tion are very rare; instead, highlighting seems very often to be combined with an interpretive element, as perhaps even in the case cited above.

Closely related to topical notes and performing a similar function are summary notes. ${ }^{41}$ Such notes commonly present an abbreviated version of the argument in the passage, either by paraphrasing the content or by directly copying parts of the formulation in the text. A case of almost direct repetition is found in fol. $307 \mathrm{v}$ in a discussion of how gold is produced. Sidrak makes clear to Bokkus that gold "In Gyse: of Brasse: Men fynde there [i.e. in western India], By the Bancke, of $y^{\mathrm{e}}$ Sea: euerywhere:". The marginal note gives basically the same information: " ${ }^{i s}$ gold, lyke, Brasse: everywheare: by $y^{\mathrm{e}}$ Bancke, of $\mathrm{y}^{\mathrm{e}}$ Sea: Men, may hit fynde". The purpose here seems to be to highlight the issue, providing easier reference to the discussion in the future. Like topical notes, straightforward summary notes are not particularly common, and they typically overlap with interpretive notes.

Language notes appear with some frequency in Sidrak and Bokkus, and there are some striking features of these notes. ${ }^{42}$ The most straightforward kind of language note consists of a translation of an English word into Latin, such as the gloss "Occassus?" (literally 'sunset' hence 'west') to accompany "Weste" (fol.307v), which is underlined in the text. ${ }^{43}$ The exact purpose of such notes is unclear: they may have a highlighting function, although why the annotator would want to gloss west is difficult to determine. A slightly peculiar trend among these notes is that the annotator frequently adds the appropriate inflection of the Latin word. The word "fyrmament", which is the most frequently glossed word in the text, has triggered the gloss "Aether. ris. rem." in fol. $162 \mathrm{v}$, where the annotator has supplied the inflectional endings for the genitive and accusative cases. Similarly, in a gloss to the verb "Blewe", the annotator gives the first and second person present forms and the infinitive form of the Latin verb: "flo. flas. flare:" (fol.167r). The adjective "Rype" has helpfully been glossed as "Matura. us. um:" (fol.318v), indicating the inflection for all the grammatical genders.

It is tempting to suggest that the annotator was using an English-Latin dictionary or glossary as he was going through the text. Such glossaries were indeed available in early modern England. A good example is John Baret's An Alvearie or Triple Dictionarie, in Englishe, Latin, and French (1574),

seems a better interpretation. See Dawson \& Kennedy-Skipton 1966, 18, and Samuel A. Tannenbaum, The Handwriting of the Renaissance (New York: Columbia UP, 1930) 143.

41 Sherman 1995, 82.

42 I have chosen a broader, more inclusive term than Sherman 1995, 82, who opts for the term translation notes. His term covers both Dee's translation of a word in the English text into another language and more general language comments.

43 For the use of the question mark, see above, fn. 40. 
and the updated version An Alvearie or Quadruple Dictionarie, Containing Foure Sundrie Tongues: Namelie, English, Latine, Greeke, and French (1580). ${ }^{44}$ These dictionaries have English words as headwords, and give the Latin, French, and, in the case of the 1580 edition, the Greek equivalent. It is quite possible that the annotator was using a dictionary similar to the Alvearies, but not very likely the Alvearies themselves. Although, like the BPH M199 annotator, they provide basic inflectional patterns for most words, they are not always the same as those of BPH M199 (e. g. different verb forms are supplied), and some words that are glossed in BPH M199 are not included in the Alvearies. It also remains unclear why the annotator would have used an English-Latin dictionary: he was clearly a native speaker of English, as most of the notes are at least partially in English. If the annotator for some reason was trying to learn Latin, the selection of glossed words is slightly unexpected. Glossing "fyrmament" is perhaps not too surprising, but "Rype" (maturus), a fairly basic term that would presumably have been known by someone with a smattering of Latin, seems a less likely item to gloss. The reason behind these glosses is thus not completely transparent.

The most frequent type of note offers an interpretation of the text. ${ }^{45} \mathrm{In}$ terpretive notes are of particular interest in that they reveal not simply what techniques were used to annotate the text, but how the text was approached. To say that every note is revelatory would be an overstatement. Some notes are very terse and cryptic, and the exegetical framework that they draw on is very difficult, if not impossible, to reconstruct. The notes also do not seem to betray a uniform reading approach. There may be several reasons for this. As suggested earlier, the notes may not all have been provided by the same reader, although a majority certainly were. The annotator may even have read the text several times, each time with a different goal or with a different interpretive framework in mind, as Gabriel Harvey read his Livy. ${ }^{46}$ Again, a detailed study of ink changes in the annotations may be able to tease out a clearer chronology.

Although some aspects of the notes remain uncertain, there are examples that clearly testify to how Sidrak and Bokkus was interpreted. The most prominent interpretive framework is alchemy. Considering the fact that BPH M199 is primarily devoted to alchemy, this is perhaps not too surprising. On the other hand, since Sidrak and Bokkus does not explicitly deal with alchemical topics, the comments exhibit a propensity to reinterpret or

44 STC ( $2^{\text {nd }}$ ed.) 1410 and 1411, available in the Early English Books Online.

45 Sherman 1995 does not include a separate category of interpretive notes. As in Sidrak and Bokkus, many examples that Sherman cites from Dee contain exegetical elements, although Sherman assigns them to the categories of topical or summary notes.

46 Jardine \& Grafton 1990. 
at least read the text in light of alchemy. Although alchemy is often defined as the pursuit of the philosophers' stone that would transmute base metals into silver or gold, recent research has shown that alchemy was much more multifaceted: the term alchemy in the sixteenth and seventeenth centuries covered a range of (al)chemical, pharmacological, and metallurgical approaches. ${ }^{47}$ Exactly what preferences or goals the annotator had is unclear, but it cannot be assumed to be the pursuit of transmutation (at least not exclusively). Alchemy should hence be understood in broad terms in the subsequent discussion.

An illustrative example of an alchemical reading occurs in Question 315 (fol. $310 \mathrm{v}$ ), where Bokkus asks Sidrak what the "fattest" thing in the world is. Sidrak's answer is earth, because things that grow come out of earth. The annotator has taken this topic in a very different direction. Two instances of "earthe" have been glossed with "sulphure/sulphur" above the line, and the phrase " $\mathrm{y}^{\mathrm{e}}$ fatnesse, of earthe" has triggered the marginal comment: " $\mathrm{y}$ e fatnes of the earthe: Is sulphur:". This slightly peculiar statement clearly indicates an alchemical interpretation. Sulfur as "the fatness of the earth" is a common notion in alchemy. It is, for instance, found in (Pseudo-)Albertus Magnus's Semita recta, a very popular medieval tract on alchemy: "Sulphur vero pinguedo terrae est in minera terrae per temperatam decoctionem inspissata, quousque induretur, et fiat spissa: et cum indurata fuerit, vocatur sulphur" - "Sulfur is the fatness of the earth made thick in the ore of the earth through temperate decoction, until it is hardened and made thick, and when it is hardened, it is called sulfur' (my translation). ${ }^{48}$ The annotator was clearly well aware of this alchemical concept.

Another revealing example represents perhaps a more radical reading. In Question 74, Bokkus queries Sidrak on why some people are black, white or brown in hue. Sidrak gives three reasons: one genetic (depending on the father and mother), one environmental (depending on living conditions), and one climate-related (depending on temperature). There are two notes of interest in this question. The first one is a bit cryptic, but shows that the annotator was thinking about the issue in metallurgical terms. In Sidrak's discussion of genetics, the annotator glosses the lines "But If the one, be Browne [i.e. the father or the mother]: and that the

47 William R. Newman \& Lawrence M. Principe, “Alchemy vs. Chemistry: The Etymological Origins of a Historiographic Mistake”, Early Science and Medicine 3 (1998): 32-65.

48 B. Alberti Magni, Ratisbonensis Episcopi, Ordinis Praedicatorum, Opera omnia, ed. Auguste \& Aemilie Borgnet (Paris, 1898) 37: 553. See also similar statements made by two other medieval alchemical authorities: (Pseudo-)Roger Bacon, The Mirror of Alchimy, Composed by the Thrice-Famous and Learned Fryer, Roger Bachon, ed. Stanton J. Linden (New York: Garland, 1992) 9-10; and (Pseudo-) Geber, The Summa Perfectionis of Pseudo-Geber: A Critical Edition, Translation, and Study, ed. William R. Newman (Leiden: Brill, 1991) 327-28. 
other be, white" with "Magnesia? et litarge?" (fol. 323v). ${ }^{49}$ Although the annotator does not elaborate on his thoughts, it seems clear that he saw a parallel to minerals and metals. This idea is strengthened by a note at the very end of the question, where Sidrak discusses climate-related reasons. He makes clear that "The Colder, lande: $\mathrm{y}^{\mathrm{e}}$ whiter, aye: for their $\mathrm{y}^{\mathrm{e}}$, Skyne; Is not Brent: all Daye./". The annotator offers an innovative reading of this statement: " $\&$ therfore is .D. [= silver] \& Albus. [sic] plumbum: whiter; then coper; for his face. vel. os. is not Burnte, with $\mathrm{y}^{\mathrm{e}}$ sone by Daye: neither. yet $\mathrm{y}^{\mathrm{e}}$.D. [= moon]. by night:". It is unclear whether this comment represents a true reinterpretation of the text (i.e. the annotator saw the text as discussing the constitution of metals), or whether it points to a parallel between metals and people. ${ }^{50}$ Irrespective of which is the more likely, the "alchemical" (in a wide sense) predilections of the annotator are clear.

Although alchemy appears to be the most prominent reading framework, not all the comments are related to it. At the same time, there does not seem to be any other reading system that is similarly pervasive: other comments appear to be more ad hoc, reflecting a number of different interests. A couple of examples will suffice. Question 23 (fol.98 r) deals with the nature of the soul. Sidrak explains to Bokkus that if a person has followed God's commandments in life, after death the soul will be given "A Clothe, of Grace", and if he or she has not, the soul will be given "A Clothe, of Sorowe". The annotator fairly straightforwardly interprets or clarifies these terms as "light, \& Joye, of heavenly. paradice" and "paynes, tormentes \& vexacion of hell: Darckenes". A similar, biblically grounded interpretation or clarification occurs in the preface to Sidrak and Bokkus. In a passage where Sidrak describes how he has managed to expel the devil (fol.106v), he explains that the four corners of the temple of the idols represent "iiij Men: $\mathrm{y}^{\mathrm{t}}$ shall tho, In .iiij. sydes, of $\mathrm{y}^{\mathrm{e}}$ Worlde, goe: That suerly manye a man shall wite, every one, his Booke shall wright". The annotator supplies the names of the four evangelists, who are the four men that the passage alludes to: “Mathew. Marcke luke. \& Joan:”.

The final category of notes consists of explicit references to other texts. ${ }^{51}$ There are only a handful of these notes. Slightly surprisingly, the references

49 It is unclear what specific substances the annotator had in mind since both litharge and magnesia were used for several different substances at the time. Magnesia probably refers to one of several compounds of magnesium, some of which are white. Litharge $(\mathrm{PbO})$ can be red, perhaps reddish brown. See OED s. vv. litharge and magnesia; $O E D=$ Oxford English Dictionary. Online at <www.dictionary.oed.com> (as accessed in 2007). For the question marks, see above, fn. 40.

50 For reinterpretations of non-alchemical texts as alchemical, see Grund 2006, 284.

51 Cf. Sherman 1995, 82-83. I have not included cross-references within the text here, since I have discussed them earlier (Section 4). 
are never to scientific or alchemical works, which may have been expected considering the manuscript context in BPH M199 and considering some of the alchemical (re)interpretations of the material. Instead, the explicit references are to literary or biblical material. The most fascinating are perhaps three references to Chaucer's Canterbury Tales, two to the Monk's Tale and one inexplicit reference, presumably to the Canon's Yeoman's Tale. The first instance appears in conjunction with Bokkus's question about how the world was created. However, the reference to the Monk's Tale here does not seem to have been triggered by an interest in the origin of the world; instead, the connection is Lucifer. Sidrak begins his answer by saying that the world was created after " $y$ e Angell, had done amysse, and was falen owt of Blisse" (fol. $161 \mathrm{v}$ ). Although Lucifer is not mentioned by name, the identity of " $\mathrm{y}^{\mathrm{e}}$ Angell" is clear. Nevertheless, perhaps it was the slightly vague reference that made the annotator add a marginal reference to the Monk's Tale, or perhaps it was meant as a reference to a parallel or to further reading. Although a couple of lines are cited, they seem merely to be intended to give a reference to further reading rather than additional information: "Therefore: I wilbegyne, At Lucifer: thowghe he weare an Angell: and not A Man: vide $\mathrm{y}^{\mathrm{e}}$ Monkes Tale: fo. 83 ".52

The second reference to the Monk's Tale presents perhaps a more unexpected parallel. In a question of where rain originates, Sidrak declares (fol. $312 \mathrm{v})$ :

Rayne: Is water, of $y^{\text {e }}$ Sea: And

he mowntythe, with $\mathrm{y}^{\mathrm{e}}$ Blaste, of Wynde

And whan $y^{e}$ Wynde, is on hye:

The Sonne, $\mathrm{y}^{\mathrm{t}}$ is hote: kyndly

drawethe, $\mathrm{y}^{\mathrm{e}}$ water faste hyme to:

The wynde puttythe faste after also:

The annotator here saw a parallel to the story about Cresus in the Monk's Tale. Within a bracket connecting to the first line in the extract, the annotator adds in the margin: "Iupiter. did washe, bothe Backe, \& syde: of Cresus, $y^{\mathrm{e}}$ Ryche kynge. of lyde:". Similarly, within a bracket connecting to the fourth line in the extract, the annotator adds: "And phebus. eke, browght hyme a fayre towell. to Drye, his weete, vide $y^{\mathrm{e}}$ Mounckes tale, folio. 87./".53 The parallel might seem a bit peculiar, but it becomes clearer if viewed in the larger context of the Cresus story in the Monk's Tale. The lines referenced in Sidrak and Bokkus are part of a dream that Cresus has. When he relates his dream to his daughter, she interprets it in the following way: "[...] Juppiter bitokneth snow and reyn, I And Phebus, with his towaille so

52 Cf. The Riverside Chaucer, gen. ed. Larry D. Benson (Boston, MASS: Houghton Mifflin, 1987) 241, 11. 1999-2000.

53 Cf. Riverside Chaucer, 251, 11. 2744-46. 
clene, I Tho been the sonne stremes for to seyn". ${ }^{54}$ The annotator clearly saw a parallel between Chaucer's text and Sidrak and Bokkus in the depiction of the rain and the sun, although the two texts do not really deal with the same topic.

In addition to providing a clue to what texts the annotator had at his disposal, the two references to the Monk's Tale are also significant in that they even suggest what version of Chaucer's Canterbury Tales he used. The folio numbers that are given at the end of each reference are a positive match with the folio numbers of the third edition of William Thynne's Canterbury Tales, printed c. 1550. According to Derek Brewer, this edition is "a bookseller's reprint" of Thynne's 1542 edition, which in turn goes back to the original 1532 edition. ${ }^{55}$ Although a reprint, the c. 1550 edition differs from the 1542 edition in placing the apocryphal Plowman's Tale before The Parson's Tale, and, crucially, the foliation of the two varies, which helps to pinpoint the third edition as the annotator's copy. ${ }^{56}$ The readings of the comments in Sidrak and Bokkus do not match perfectly those of the Chaucer edition, but this is perhaps not to be expected since the annotator does not seem to have been concerned to keep the meter and rhyme scheme.

The third Chaucer reference is the most elusive. The annotator simply glosses "An Earthen, pot" in the margin with "Chausers earthen pot" (fol. $103 \mathrm{r})$. The reference here is presumably to the Canon's Yeoman's Tale, where the yeoman mentions an "erthen pot" to be used for the alchemical experiments that he describes. ${ }^{57}$ Exactly what connection the annotator saw between the passage in Sidrak and Bokkus and the Canon's Yeoman's Tale is unclear. The context is certainly not alchemical in Sidrak and Bokkus: at the advice of an angel, Sidrak uses an elaborate scheme involving an earthen pot to drive out the devil and demonstrate God's power. However, as we have seen above in the discussion of interpretive notes, non-alchemical passages have elsewhere in BPH M199 been (re)interpreted in light of an alchemical or metallurgical framework, so the annotator might even have seen some alchemical significance in this passage. ${ }^{58}$ The fact that the reference is to Chaucer's text, which has, at best, an ambiguous stance towards

54 Cf. Riverside Chaucer, 251, 11.2752-54.

55 Geoffrey Chaucer: The Works, 1532, with Supplementary Material from the Editions of 1542, 1561, 1598 and 1602, ed. Derek Brewer (London: Scolar P, 1969) unpaginated.

56 Brewer 1969, unpaginated. Brewer notes four different imprints of the c. 1550 printing. All of them have the same folio numbers as those given by the annotator (although the annotator's fol. 83 is fol. $83 \mathrm{v}$ in all the imprints). The four versions are all available in the Early English Books Online.

57 Riverside Chaucer, 272, 1. 761.

58 See also Grund 2006, esp. 284. 
alchemy, does not imply that the annotator did not see the passage as genuinely interesting from an alchemical point of view. There is plenty of early modern evidence for the Canon's Yeoman's Tale being read as a work containing useful alchemical information. ${ }^{59}$

Among the remaining references are two to the Bible, one to Virgil, and one to "The Travaylyd, pilgrime". Like the Chaucer references, these seem all to point out parallels or further reading. The first biblical citation (fol. $308 \mathrm{r}$ ) seems to be to 1 Corinthians, but the reference is heavily abbreviated and thus not completely certain. The annotator references it "for $y^{\mathrm{e}}$ expocicion of Exustio". The only parallel in 1 Corinthians is $3: 15$, which mentions burning. However, the context is completely unrelated to the discussion of Sidrak and Bokkus, which describes where sulfur comes from. The second reference (fol. 316v) is to Matthew's (3:11) account of John the Baptist. The quotation appropriately accompanies Sidrak's comment that the son of God will baptize many people "In forgyvenes, of their Synne". Finally, the annotator glosses "his [i.e. God's] foes. in hell: weare subiecte" with "Celum, solvere. in Tartara: virgell” (fol.169v), paraphrasing book twelve of the Aeneid: "caelumque in Tartara soluat". ${ }^{60}$

A more contemporary work is cited in fol. $161 \mathrm{r}$, in the same passage as the first reference to the Monk's Tale: “The Travaylyd, pilgrime". The text referenced is the allegorical poem written by the clergymen Stephen Batman (c. 1542-1584) and published in 1569, which describes the human being's travails and ultimate defeat by death. ${ }^{61}$ Accompanying the references are the first two lines of the poem: “The Mightie Iove, celestiall, where firste he tooke in hande: That Chaos huge; he Made to fall: And formid so a lande". These lines go very well with this particular question in Sidrak and Bokkus, which concerns the creation of the world. Since Batman's poem moves away from this topic after the two introductory lines, it is unlikely that the annotator noted them to indicate further reading (as seems to be the case with at least two of the Chaucer references). It may only have been noted as a parallel.

59 George R. Keiser, “The Conclusion of the Canon's Yeoman's Tale: Readings and (Mis)Readings", Chaucer Review 35 (2000): 1-21.

60 Virgil, Aeneid, Book XII, ed. W.S. Maguinness (London: Bristol Classical P, 1992) 1.205.

61 Oxford Dictionary of National Biography, <http://www.oxforddnb.com> (as accessed in 2007); Stephen Batman, The Trauayled Pylgrime (London: Henrie Denham, 1569), STC ( $2^{\text {nd }}$ ed.) 1585 , available in Early English Books Online. 


\section{Concluding Remarks}

For a period where we have limited access to how readers responded to particular texts, BPH M199's Sidrak and Bokkus provides a rare window to the practices of reading and interpretation in the early modern period. BPH M199 reveals a copyist who carefully selected questions from the original text that particularly interested him and put them in a sequence that helped him deal with the topics or contents of what he had already read. The picture of a person involved in serious study also emerges from the multifaceted marginal notes. He saw parallels to the contemporaneous Travailed Pilgrim by Stephen Batman and to the text of Chaucer's Canterbury Tales as found in the third printing of William Thynne's edition; he made astute connections to alchemical lore; and he provided cross-references and reading cues that would help him quickly access information in the future. In excerpting Sidrak and Bokkus "for [his] better vnderstandynge", the copyist clearly did us a service, enhancing our understanding of the reception and interpretation of Sidrak and Bokkus in the early modern period.

UPPSALA

Peter Grund 